\title{
Larry Smith and world Englishes
}

\author{
Kingsley Bolton ${ }^{1}$ | Daniel R. Davis ${ }^{2}$ \\ ${ }^{1}$ School of Humanities, Nanyang Technological University, Singapore \\ ${ }^{2}$ Department of Language, Culture, and Communication, University of Michigan-Dearborn, \\ USA \\ Correspondence \\ School of Humanities, Nanyang Technological University, Singapore \\ Email: kbolton@ntu.edu.sg
}

\section{Abstract}

This article discusses the contribution of Professor Larry E. Smith to the field of world Englishes (WE), a linguistic and educational enterprise in which Professor Smith was a founding figure. The article traces the development of Smith's thinking on world Englishes from early attempts to theorize English as an 'international auxiliary language' (EIAL), to a full theorization of world Englishes as a dynamic new field of study in the 1980s and 1990s. This discussion of Larry Smith's work also acknowledges his contribution to such other related areas of study as intercultural communication, and intelligibility studies, as well as his enduring contribution to the World Englishes journal, and the International Association for World Englishes (IAWE).

\section{1 | INTRODUCTION}

Larry Smith's first encounter with English language teaching was as a member of the Peace Corps in Thailand during the 1960s, after which he took up graduate studies at the University of Hawai'i, followed by various teaching and administrative posts at the University's renowned East-West Center. This article surveys his contribution to world Englishes research, publications, and other activities from the 1970s until his premature passing in 2014. Larry Smith's interest in English worldwide was initially expressed through an early theorization of English as an International Auxiliary Language (EIAL), although through his collaboration with Braj B. Kachru crystalized into the paradigm-shifting movement to establish world Englishes as a sub-discipline of linguistics, of direct relevance to both applied linguistics and sociolinguistics.

\section{2 | ENGLISH AS AN INTERNATIONAL AUXILIARY LANGUAGE (EIAL)}

Larry Smith's early thinking on world Englishes developed out of his own first-hand experience as a teacher of English with the US Peace Corps in Asia in the late 1960s and early 1970s, and his later experience as a teacher trainer at the East-West Center at the

This is the author manuscript accepted for publication and has undergone full peer review but has not been through the copyediting, typesetting, pagination and proofreading process, which may lead to differences between this version and the Version of Record. Please cite this article as doi:

10.1111/weng. 12331 .

This article is protected by copyright. All rights reserved. 
University of Hawai'i. In the early seventies, Larry published a number of articles on English language teaching and teacher training, but his first attempt at theorizing the field was an article published in the RELC journal in 1976, entitled 'English as an International Auxiliary Language', in which he emphasized the existence of numerous varieties of English worldwide. Thus, Smith (1976) defined EIAL in the following terms:

My operational definition of an international language is one which is used by people of different nations to communicate with one another. English is the most frequently used international language. My operational definition for auxiliary language is a language, other than the first language, which is used by hationals of a country for internal communication. English also frequently serves this purpose. (Smith, 1976, p. 38)

He then went on to note that 'there is a single English language but many varieties', comparing the features of American English with those of Singapore, arguing strongly that as English is an 'international auxiliary language', 'it belongs to all of us', explaining that:

\footnotetext{
English is one of the languages of Japan, Korea, Micronesia, and the Philippines. It is one of the languages of the Republic of China, Thailand, and the United States. No one needs to become more like Americans, the British, the Australians, the Canadians or any other English speaker in order to lay claim on the language. To take the argument a step further, it isn't even necessary to appreciate the culture of a country whose principal language is English in order for one to use it effectively. [...] English is a language of the world. If you accept this argument, then it is time to stop calling it a foreign language or second language. The name should be EIAL (English as an International Auxiliary Language) which more accurately reflects the present state of English language usage around the globe. (Smith, 1976, p. 39)
}

Later in the same article, Smith proceeded to argue that it was high time to change the vocabulary of English language education in the US and elsewhere, and to change EFL/ESL/ESOL programs to EIAL programs, which would have important consequences for educational linguistics, so that, at an affective level:

English can and should be de-nationalized. It could then become an auxiliary language of any country wishing to teach it. As an auxiliary language, English may or may not be parallel to the national language but it is one of the languages of the country and the students then are speakers of Thai English, Filipino English, Korean English, etc. (Smith, 1976, p. 41)

At the same time, Smith also argued for a changed attitude to the English spoken by foreigners, so that '[t]olerance can be gained by exposure to speakers of a variety of Englishes but students must be taught to expect differences, accept them, and not be upset by them' (Smith, 1976, p. 41). He also went on to explain that one should also be aware and tolerant of rhetorical, pronunciation, and structural differences between varieties of English from around the world. The article finished with a heartfelt plea to radically change pedagogical attitudes in the field of English language education, with Smith urging educators to 'stop calling the English we teach a FOREIGN or SECOND language or even ESOL and begin to call it an international auxiliary English', and arguing that the goal for teaching English is not to teach students about English culture, but rather, 'it is to extend the ability of our students to communicate their ideas and their culture. It is to help them learn about all other cultures, and to be better able to participate in the world community which includes their home town as well as their country's capital' (Smith, 1976, p. 42). 
Following Smith's (1976) article, the next major landmark in the early history of world Englishes came out of a foundational conference held at the University of Hawai'i on the topic of English for international and intranational purposes, which was explicitly arranged in order to discuss the issues that had been identified in Smith's 1976 article. The volume that emerged from that conference was entitled English for cross-cultural communication, and was edited by Larry Smith, with an introduction from Braj B. Kachru and Randolph Quirk, and contributions from Christopher Candlin, Jack C. Richards, Peter Strevens, H. H. Stern, Mary Tay, and others. According to Kachru and Quirk, the conference had a major innovative event, and one that had demonstrated that English was not only the language of Britain and the US, but also 'that it now also carries an increasing weight of African and Asian experience' and 'that this has given birth to new Englishes which [in Achebe's words] are "in communion with [their] ancestral home but altered to suit [their] new ... surroundings" - new surroundings which include the sociocultural and linguistic contexts of Africa, Asia, and the Caribbean nations' (Kachru \& Quirk, 1981, p. xx).

The 1981 volume was followed two years later by a second edited volume dealing specifically with EIAL, with the title Readings in English as an international language, published by Pergamon Press in 1983. This volume reprinted a number of foundational articles dealing with EIAL and world Englishes, by such writers as Michael Clyne, Braj B. Kachru, and Peter Strevens, among others. The volume included no less than three contributions from Smith himself, including one reprinted article from a Japanese journal Gaikokugo, on the topic of 'English as an international language', with the subtitle 'No room for linguistic chauvinism'. In this essay, Smith argued strongly for the multicultural potential of English as an international language, explaining how English could be used to communicate a wide range of national cultures:

When any language becomes international in character, it cannot be bound to any one culture; A Thai doesn't need to sound like an American in order to use English well with a Filipino at an ASEAN meeting. A Japanese doesn't need an appreciation of a British lifestyle in order to use English in his business dealings with a Malaysian. [...] The political leaders of France and Germany use English in private political discussions but this doesn't mean that they take on the political attitudes of Americans. [...] English, when used as an international language, is not owned by its native speakers [...] and native and non-native speakers everywhere must become aware of the widespread shift in attitudes and assumptions about the language. (Smith, 1983, pp. 7-8)

In this same essay, Smith also highlighted the importance of the notion of intelligibility, as well as grammatical acceptability and appropriateness, explaining that, in order to avoid linguistic chauvinism, there was a need for tolerance, particularly concerning the pronunciation patterns of international speakers of the language. At the same time, Smith also argued for the multiculturalism of international English, noting that while there is an inextricable link between language and culture, English was not necessarily linked to the cultures of such Inner Circle societies as the US, Canada, Britain, Australia and New Zealand. Smith also set out a number of guidelines for intercultural communication, which included natural speech, the avoidance of slang, jargon, and verbosity, the use of questions and paraphrase to check on comprehensibility, and the awareness of cultural differences in speech and communication. He finally concludes with a plea for diversity, and the claim that the use of English should not necessarily involve the cultural domination of the Americans or the British: 
The spread of English is not a homogenizing factor which causes cultural differences to disappear, but the use of English offers a medium to express and explain these differences. [...] Native speakers must realize that there are many valid varieties of English and that non-native speakers need not sound like or act like Americans, the British, or any other group of native speakers in order to be effective English users. English is being used as an international language in diplomacy, international trade, and tourism. Native speakers need as much help as non-natives when using English to interact internationally. (Smith, 1983, p. 11)

\section{3 | FROM EIAL TO INTERCULTURAL COMMUNICATION}

A third important book from Larry Smith in the 1980s was the collection Discourse across cultures: Strategies in world Englishes, which came out in 1987. This volume included chapters from such researchers as Andrew Gonzalez, Braj B. Kachru, Christopher Candlin, Elaine Tarone and George Yule, Henry Widdowson, Michael Clyne, Peter Strevens, Wimal Dissanayake and Mimi Nichter, and Yamuna Kachru. This volume represented a slight shift in Larry Smith's intellectual interests at the time, where he highlighted the importance of discourse analysis in relation to cross-cultural communication. In the introductory chapter, Smith argued for recognizing the phenomena as 'the place of silence, appropriate topics of conversation, forms of address, and expressions of speech-acts [...] are usually not the same across cultures and that these are perhaps more important to effective crosscultural communication than grammar, lexis, or phonology' (Smith, 1987, p. 1). Smith was also careful to discuss some of the complexities of intercultural communication even when English is used as an international link language:

\footnotetext{
It is true that language and culture are inextricably tied together, and that it is not possible to use a language without a culture base. However, one language is not always inextricably tied to one culture. English already represents many cultures and it can be used by anyone as a means to express any cultural heritage and any value system. Using English does not make one a different person. There is no need to become more 'Western' or 'Eastern' in order to use it well. (Smith, 1987, p. 3)
}

In the final section of this chapter, Smith suggests that many discourse-related problems in cross-cultural communication are the result of the following two errors: (i) using the discourse strategies of one's mother tongue when communicating in another language; and (ii) believing that there is only one correct strategy for communicating in English. Once again, Smith underlined the complexity of intercultural communication in a range of international settings. This volume on discourse across cultures highlighted an interest of Larry Smith's in cross-cultural communication that would endure and grow over succeeding years, with other book-length studies of the subject, including Changing representations of minorities East and West: Selected essays (1996a), and Multiculturalism and representation: Selected essays (1996b), both co-edited with John Rieder; Transnational Asia Pacific: Gender, culture and the public sphere (1999) with Shirley Geok-Lin Lim and Wimal Dissanayake; and Cultures, contexts, and world Englishes (2008) with Yamuna Kachru.

The 2008 volume co-authored with Yamuna Kachru provided the space for an extended discussion of cross-cultural and intercultural issues from a world Englishes perspective. Following the Introduction, the book has three substantive parts: Part I: 'Verbal Interaction and Intelligibility'; Part II 'Sound, Sentence, and Word'; and Part III: 'Conversational and Writing Styles'. The final section of the volume in a Conclusion, which discusses the 
relevance of such topics to world Englishes. Part I, 'Verbal Interaction and Intelligibility,' has chapters on verbal interaction, the context of culture, politeness, and intelligibility. Part II focuses on phonological, grammatical and lexical variation in world Englishes, with examples from American, British, Indian, Nigerian, and Singaporean Englishes, as well as other varieties worldwide. Part III discusses the conventions of spoken and written modes of communication, and how these vary between cultures, with chapters on conversational interaction, interaction in writing, and world literatures in English. The Conclusion of the book discusses a range of issues related to attitudes and ideologies, questions of relevance to language policies as well as linguistic diversity:

Concerns that arise due to attitudes and ideologies fall into two major categories: first, the place of Englishes in language policy and planning in the Three Circles, their educational, linguistic, and societal implications, and their standardization and codification; and second, as the Englishes assume positions previously occupied by local languages in educational, professional, and other domains, the ideological questions of preserving linguistic diversity and linguistic human rights. (Kachru \& Smith, 2008, p. 178).

With reference to the latter issue of linguistic diversity, Kachru and Smith note that smaller languages whose survival is threatened are usually not displaced by English, but that, in the majority of cases, 'it is the regional, or state, or national languages that are taking over the public domains of language use as universal education spreads and populations that relied on their local languages for most of their purposes gain horizontal mobility in space and vertical mobility in economic status' (p. 181).

Finally, Kachru and Smith conclude their wide-ranging survey of world Englishes and crosscultural communication with a plea for the awareness of the importance of variation in world Englishes. Thus they argue that all users of English need 'to develop sensitivity to more than one variety of English' and that educators 'have to realize that accommodating variation ins the key to success in communication across cultures in varied contexts of use', noting the applicability of WE theory and research findings to multiple areas of linguistic inquiry, so that:

The topics raised here-those of policy and planning as relevant to societal use of language, reconciling linguistic human rights with variation in language on the one hand and the need to standardize and codify in the current sociopolitical and economic world order on the other hand, and bringing the insights from studies in literacy and cognitive bases of language acquisition to bear upon language education-all these are within the concerns of world Englishes research. (Kachru \& Smith, 2008, p. 182)

Larry Smith's concerns with such issues were motivated by a number of considerations, but one consistent theme in many of Smith's writings is the need to respect the users of all varieties of English, and, indeed, the users of all languages. In the case of world Englishes, it was important, in Kachru and Smith's view, to adopt an approach 'that does not devalue any variation', but one that 'attempts to study the functions of varieties in their contexts and how they empower their users to realize certain goals (Kachru \& Smith, 2008, p. 182). 


\section{4 | THE QUESTION OF INTELLIGIBILITY}

Larry Smith was a pioneer researcher on the issue of the 'intelligibility' of various Englishes worldwide, and in the 1980s published a number of research studies that investigated this topic. One of the first, if not the very first, of these was an article co-authored with Cecil Nelson in 1985, published in an early issue of the World Englishes journal. In Smith and Nelson (1985), the two researchers survey the research literature on the topic for the years 1950-1985. Based on their analysis of this, they were then able to draw the following broad conclusions, summarized as follows:

(i) That the issue of the intelligibility of varieties of English has a history of at least 200 years, and that this is 'a natural phenomenon which will continue';

(ii) That 'native speakers' are no longer the sole arbiters of intelligibility in English, and that 'intelligibility studies are now concerned with interactions between non-native English speakers, between native English speakers of different national varieties, and between native and non-native English speakers';

(iii) Native speakers are not always more intelligible than non-native speakers;

(iv) Intelligibility is not speaker- or listener-centered but is interactional between speaker and listener;

(v) The greater the involvement of a listener has with a variety of English and its speakers, the greater the likelihood that he/she will find that person or variety intelligible, and the greater the familiarity a speaker has with a variety of English, the more likely it is that he/she will be intelligible to members of that speech community;

(vi) The expectations of the listener are extremely important, so that if one expects to understand a speaker, he/she is much more likely to find the speaker intelligible than if he/she does not expect to understand them. (Smith \& Nelson, 1985, p. 333)

It was, very interestingly, that, in this early article on the topic, we find the tri-partite distinction between intelligibility (word/utterance recognition), comprehensibility (word/utterance meaning, locutionary force), and interpretability (meaning behind word/utterance, illocutionary force).

These distinctions were also utilized in a subsequent study in a research study entitled 'Language spread and issues of intelligibility' authored by Smith and published in 1988. In this foundational empirical study, Smith gave tests of intelligibility to three groups of subjects: (i) 'non-native speakers' of English (NNS); (ii) 'native speakers' of English (NS); and (iii) 'mixed' (NNS and NS). The specific research questions for this study were '(1) what differences, if any, there are in the intelligibility, comprehensibility, and interpretability of selected taped material of nine national varieties; (2) how familiarity of topic and familiarity of national variety influence the listener's understanding of these varieties; and (3) if the language proficiency of the speaker and/or listener influence/s the intelligibility, comprehensibility, and interpretability of these varieties' (Smith 1988, p. 266). Subjects in the study were tested on their responses to nine national varieties of English, recorded by 'educated speakers' (students at the University of Hawai'i and other tertiary institutes) of the Englishes of China, India, Indonesia, Japan, Papua New Guinea, the Philippines, Taiwan, the United Kingdom, and the United States.

The NSS group of 'non-native' speakers were constituted by ten Japanese students studying in Honolulu, while the NS 'native speaker' subjects were all undergraduate students at the University of Hawai'i. The 'mixed' group was composed of one native and eight non-native speakers, from various countries, including Burma, China, Indonesia, Japan, Korea, the Philippines, Thailand, and the United States. The design of the test involved the 
various speakers explaining to an interlocutor from another country the forms of address used by the speakers' fellow nationals when addressing outsiders at an international meeting. These conversations were tape-recorded and then edited into ten-minute recordings, which then became the basis for the comprehensibility and interpretability tests. Three types of test questions were then developed, which included a cloze exercise to test intelligibility (word/utterance recognition), multiple-choice questions to test comprehensibility (word/utterance meaning), and a paraphrase procedure to test interpretability (meaning behind word/utterance).

The results of the experiments indicated that all three subject groups (NNS, NS and mixed) did relatively well on the test of intelligibility, although some Japanese subjects in the NNS groups had noticeable problems of intelligibility with speakers from the UK in interaction with Papuans (score of $70 \%$ ), as well as with Chinese speakers of English (90\%). However, there were much lower scores across the groups in relation to comprehensibility (with average scores ranging from $60 \%-97 \%$ ), and when it came to the issue of interpretability, the results indicated that the mixed group performed best on tasks involving the interpretation of meaning, with Smith reporting that:

It is evident that the mixed subjects (one native and eight nonnatives, each from a different country), who had the greatest familiarity with different speech varieties, were best able to interpret correctly (i.e. know meaning behind word/utterance) the interactions of the five pairs of interactors. [...] This part of the study offers supporting evidence that familiarity with several different English varieties makes it easier to interpret cross-cultural communication in English. No doubt this is influenced by the fact that familiarity with different speech varieties also involves an awareness of cultural differences and some knowledge of different cultures. (Smith, 1988, p. 274)

Smith (1988, p. 276) also proceeded to add that '[i]t is clear that the mixed group of subjects, which was most familiar with different national varieties of English, had the most confidence in their ability to understand the conversations'. In the conclusion to the article, Smith noted a number of important points. First, that there was evidence from the results of major differences between intelligibility, comprehensibility, and interpretability, and that '[b]eing able to do well with one does not ensure that one will be able to do well with the others'. Second, that those respondents who were familiar with different varieties of English performed better on the tests of interpretability than those who did not, and, third, that native speakers (from the UK and the US) were not found to be the most easily understood nor the best able to understand the different varieties of English (Smith, 1988, pp. 280-281).

This was an important study for a number of reasons, including the fact that it was one of the first empirical studies that moved forward the research agenda on intelligibility that had earlier been outlined in in Smith and Nelson (1985). It was also of major importance in indicating that intelligibility in all its facets was not simply a problem of articulation for 'nonnatives', but was a theoretical and research question of central importance for world Englishes research at a number of levels. This early work on intelligibility in the 1980s also established a foundation for subsequent research that would build upon these early studies, including Smith (1992, 2003, 2009), Smith and Christopher (2001) and Smith and Nelson (2006), Berns (2008), Bhatia (2008), Y. Kachru (2008), Nelson (2008, 2011). Smith's contribution to this field was innovative and inspiring, as Braj B. Kachru highlighted in his contribution to the symposium on 'Intelligibility and Cross-cultural Communication in World Englishes' that was published by this journal in 2008. In that article, Professor Kachru 
recognized the impact of 'the Smith paradigm for intelligibility in world Englishes', which, he noted, had developed out of Larry Smith's first-hand experiences of such questions in a range of cross-cultural contexts, which 'demonstrated deep understanding of his experience in East Asia, particularly in Thailand, and his collaborative empirical research with the participants at the East-West Center - Japanese, Singaporeans, Chinese, Afghans, and South Asians (Kachru, 2008, pp. 293-294).

\section{5 | CONCLUSION}

Larry Smith's contribution to world Englishes was multi-faceted and multi-talented. As indicated in the preceding sections of this article, Larry made a singular contribution to at least two core areas of world Englishes scholarship, namely cross-cultural communication (through his work with Yamuna Kachru) and intelligibility studies (where he worked closely with Cecil Nelson). In many areas of his work, Larry was always a team player, always a willing collaborator on innovative projects in education and linguistics, and very often a team leader as well, in his work at the East-West Center at the University of Hawai'i (from 1970-1999), in his role as Executive Director of the International Association for World Englishes (IAWE) from 2003 to 2010 and President of IAWE from 1993 to 1996, as well as in his later career with Christopher Smith and Associates, a consultancy company that specialized in leadership training. Larry Smith's collaborations were not limited to areas of linguistics and language studies, but extended to such other areas as cultural studies, gender studies (Masavisut et al., 1995; Lim et al., 1999), and multiculturalism and ethnic minorities (Smith \& Rieder, 1996a, 1996b). It was in his collaboration with Braj B. Kachru that Larry arguably made his greatest contribution to both international education and linguistics, in particular, through the founding of the international journal World Englishes, originally published by Pergamon Press, but today, a Wiley journal. When the journal was first published, it was an innovative and paradigm-shifting event, as the two co-editors were well aware. From the beginning, the journal was distinguished not only by its recognition of Englishes in the plural, but also by its wide commitment to diversity and inclusivity, as the editors' own policy statement avowed:

WE is intended for students, researchers and teachers of language, literature, and the methodology of English teaching. The aim is to provide an international outlook on these areas of research. The approach is integrative and aims at exploring the relationships in the study and teaching of English language and literature. [...] The editorial board considers the native and non-native users of English as equal partners in deliberations on users of English and its teaching internationally. The acronym WE, therefore aptly symbolises the underlying philosophy of the journal and the aspirations of the Editorial Board. (Kachru \& Smith, 1985, p. 211)

Over the three decades that have followed, the World Englishes journal has consistently followed this mission, and has pioneered many branches of study related to world Englishes in the widest possible sense, publishing not only areal and features-based studies of world Englishes, but many other contributions dealing with such topics as applied linguistics, codeswitching and code-mixing, discourse analysis, language contact, language and globalization, language policies, linguistic landscapes, linguistic and literary creativity, linguistic imperialism, multilingualism, and much more. Over these years, Larry Smith was the caring and nurturing member of a creative intellectual partnership that not only produced the very 
journal where this article is now published, but also the world Englishes association, the International Association for World Englishes (IAWE), which has had a remarkably successful history in conducting conferences in so many different countries and regions across the globe, including Australia, Canada, China, Germany, Hawai'i, Hong Kong, India, Japan, Philippines, Singapore, South Africa, Turkey, and the USA.

Larry Smith contributed to much of the success of both the journal and the association in his own individual and low-key fashion, doing a great deal for the WE enterprise that was unannounced and undeclared, often involving extensive overseas travel to regions such as the Middle East and the former Soviet Union in order to carry the world Englishes message. In his writings and in his personal and professional life, Larry was a thought leader as an advocate for international dialogue and international understanding. The authors of this article personally witnessed on many occasions Larry's charismatic ability to talk to academics, linguists and ordinary folk from many different countries, religions and social classes. For Larry, the cause of world Englishes was heartfelt and personal, and likely grounded in a spirituality that Larry Smith often displayed, but never paraded and rarely discussed. His views on English language learning and world Englishes were grounded in a respect for all the people of the world, as well as an awareness of and resistance to English linguistic imperialism, as he explained in a 2006 interview at the East-West Center (Sines, 2006). As noted at the very beginning of this article, in one of his first essays on English as an international language, Larry argued passionately that there was simply 'no room for linguistic chauvinism', and this was a core belief that he maintained throughout the whole of his life as an innovative linguist and an inspirational educator.

\section{REFERENCES}

Berns, M. (2008). World Englishes, English as a lingua franca, and intelligibility. World Englishes, 27(3-4), 327-334.

Bhatia, V. K. (2008). Creativity and accessibility in written professional discourse. World Englishes, 27(3-4), 319-326.

Kachru, B. B. (2008). The first step: The Smith paradigm for intelligibility in world Englishes. World Englishes, 27(3-4), 293-296.

Kachru, B. B., \& Smith, L. E. (1985). Editorial. World Englishes, 4(2), 209-212.

Kachru, B. B., \& Quirk, R. (1981). Introduction. In L. E. Smith (Ed.), English for cross-cultural communication (pp. xiii-xx). London: Macmillan.

Kachru, Y. (2008), Cultures, contexts, and interpretability. World Englishes, 27(3-4), 309318.

Kachru, Y., \& Smith, L. E. (2008). Cultures, contexts, and world Englishes. London: Routledge. Lim, S. G.-L., Smith, L. E., \& Dissanayake, W. (1999). Transational Asia Pacific: Gender, culture and the public sphere. Urbana, IL: University of Illinois Press.

Masavisut, N., Simson, G., \& Smith, L. E. (Eds.). (1995). Gender and culture in literature and film East and West: Issues of perception and interpretation: Selected conference papers. Honolulu: College of Languages, Linguistics, and Literature, University of Hawai'i: EastWest Center.

Nelson, C. L. (2008). Intelligibility since 1969. World Englishes, 27(3-4), 297-308.

Nelson, C. L. (2011). Intelligibility in world Englishes: Theory and application. New York: Routledge. 
Sines, A. (2006). Interview narrative of Larry E. Smith. East-West Center Oral History Project Collection. Honolulu, Hawai'i: East-West Center.

Smith, L. E. (1976). English as an international auxiliary language. RELC Journal, 7(2), 38-42. Smith, L.E.(Ed.). (1981). English for cross-cultural communication. London: Macmillan.

Smith, L. E. (Ed.). (1983). Readings in English as an international language. Oxford: Pergamon Press.

Smith, L. E. (Ed.). (1987). Discourse across cultures: Strategies in world Englishes. London: Prentice Hall.

Smith, L. E. (1988). Language spread and issues of intelligibility. In J. E. Alatis (Ed.), Language spread and language policy: Issues, implications and case studies (Georgetown University Round Table on Languages and Linguistics 1987) (pp. 265-282). Washington, DC: Georgetown University Press.

Smith, L. E. (2003). English across cultures: The problem of intelligibility. In G. French \& J. d'Angelo (Eds.), First conference on world Englishes in the classroom: Proceedings (pp. 52-59). Nagoya: Chukyo University College of World Englishes.

Smith, L. E. (2009). Dimensions of understanding in cross-cultural communication. In K. Murata \& J. Jenkins (Eds.), Global Englishes in Asian contexts: Current and future debates (pp. 17-25). New York: Palgrave Macmillan.

Smith, L. E. (1992). Spread of English and issues of intelligibility. In B. B. Kachru (Ed.), The other tongue: English across cultures (pp. 75-90). Urbana: University of Illinois Press.

Smith, L. E., \& Nelson, C. L. (1985). International intelligibility of English: Directions and resources. World Englishes, 4(3), 333-342.

Smith, L. E., \& Christopher, E. M. (1987). Leadership training through gaming: Power, people and problem-solving. New York: Nichols Pub. Co.

Smith, L. E., \& Rieder, J. (Eds.). (1996a). Changing representations of minorities East and West: Selected essays. Honolulu: University of Hawai'i Press.

Smith, L. E., \& Rieder, J. (Eds.). (1996b). Multiculturalism and representation: Selected essays. Honolulu: University of Hawai'i Press.

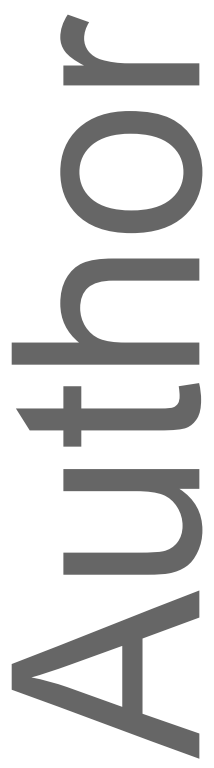

This article is protected by copyright. All rights reserved. 